\title{
Lactate dehydrogenase and glutamic oxalacetic transaminase of the cerebrospinal fluid in tumours of the central nervous system
}

\author{
G. A. B. DAVIES-JONES 1 \\ From the Department of Neurology, United Sheffield Hospitals
}

Glutamic oxalacetic transaminase (GOT) and lactate dehydrogenase (LD) are present in high concentration in nervous tissue. Reports concerning the presence of these enzymes in the cerebrospinal fluid in various neurological diseases began appearing about the mid-1950s, and numerous publications have since documented changes in the GOT and LD activity of the CSF that have accompanied some diseases of the nervous system.

Because of the conflicting results that were reported regarding these enzyme changes in the CSF, these parameters were again studied in various neurological diseases. In all, 500 patients were studied, from a number of whom interesting results were found. The group of patients with neoplastic disease of the nervous system was associated with such findings. This comprised 18 patients with primary tumours and 18 patients with metastatic tumours of the central nervous system.

\section{METHODS}

The lactate dehydrogenase activity of the CSF was determined spectrophotometrically by the method of Wróblewski and LaDue (1955). The glutamic oxalacetic transaminase activity was measured spectrophotometrically following the method of Karmen (1955). The phosphate buffer was made as required and the $p H$ adjusted to between $7 \cdot 45$ and $7 \cdot 55$. All other reagents were obtained from the Sigma Chemical Company Ltd. Fresh solutions of reduced nicotinamide-adenine-dinucleotide were made for each batch of tests, as potent enzyme inhibitors may form in solutions, even if frozen (Fawcett, Ciotti, and Kaplan, 1961). All measurements were made at a constant temperature of $25^{\circ} \mathrm{C}$.

Approximately 5 to $6 \mathrm{ml}$. of CSF was obtained by lumbar puncture, and after gentle mixing half of this sample was taken for routine estimation of protein, cell count, and colloidal gold reaction. The remaining half was immediately frozen and kept in the ice box until the time of estimation of the enzyme content, which was always done within a week of obtaining the CSF. Any

${ }^{1}$ Now at Department of Neurology, United Oxford Hospitals.
CSF sample containing more than 10 red blood cells/cu. $\mathrm{mm}$ was discarded, as sanguineous CSF yields a falsely elevated enzyme content. Storage of the CSF produced a decrease in the enzyme content over 11 days of less than $1 / 100$ of its original activity. This reduction was negligible and could be ignored. This accords with the observation of Green, Oldewurtel, O'Doherty, Forster, and SanchezLongo (1957) who found that refrigeration of the CSF for two weeks did not influence the results. The mean difference in duplicate estimations of LD and GOT content of the CSF was 0.2 and 0.3 units respectively. The respective standard error of the mean difference waso $\pm 0 \cdot 12$ and $\pm 0 \cdot 13$. Statistical analyses of the results were calculated using Student's $t$ test for the significance of the difference of the means.

Eighteen patients with primary tumours of the centrale nervous system and 18 patients with metastatic carcinoma of the CNS were studied. The control group of 44 patientso was composed of 26 patients in whom no evidence of disease was found. The remaining 18 patients were diagnosed as suffering from depression (3), hysteria (3), anxiety (1), functional head pain (1), thoracic outlet syndrome (2), congenital nystagmus (1), entrapment ulnar neuropathy (1), post-herpetic neuralgia (1), labyrinthitis (3), pneumonia (1), and infective hepatitis (1).

\section{RESULTS}

The mean LD content of the control group was $17 \cdot 5$ units $/ \mathrm{ml}$. with a standard deviation of $\pm 7 \cdot 7$ units. The mean GOT value was $9 \cdot 1$ units $/ \mathrm{ml}$. with a standard deviation of \pm 3 units. The upper normal limit for LD activity was therefore 32.9 units $/ \mathrm{ml}$. and that for the GOT activity was $15 \cdot 1$ units $/ \mathrm{ml}$.

Tables I and II display the values of these CSF enzymes in patients with metastatic and primary tumours of the central nervous system respectively.

In the group with primary tumours, the LD content of the CSF was normal in all cases, apart from one patient who had a value of 35 units in association with a glioma of the optic nerve and one other patient with a grade IV temporo-parietal astrocytoma and a CSF LD activity of 150 units. The mean LD activity of 26.9 units was not statis- 
tically significantly different from the control group $(t=1.86, P<0.1>0.05)$. If the value of 150 units were excluded, the mean LD activity would be 19.6 units, well outside the range of statistical significance $(t=0.99, P<0.4>0.3)$. The transaminase activity in each case was normal, but two patients with temporal lobe gliomata had high normal values of 15 units each. The mean transaminase activity of 9.7 units showed no significant difference from the control group $(t=0.71, P<0.5>0.4)$.

The group of patients with metastatic tumours of the nervous system showed a highly significant difference in the mean CSF LD activity of 67 units $(t=6.87, P<0.001)$. Indeed all but two patients in the group had significantly elevated individual results. Similarly in all but two patients the CSF transaminase activity was significantly raised. The mean transaminase activity of 20.4 units again was highly significantly different from the control group $(t=10 \cdot 2, P<0.001)$.

\section{DISCUSSION}

These results of normal CSF LD and GOT activities in patients with primary tumours of the nervous system are in agreement with those of Fleisher, Wakim, and Goldstein (1957), Wróblewski, Decker, and Wróblewski (1957), Green et al. (1957), Katzman, Fishman, and Goldensohn (1957) and Mann, DePasquale, and Paterson (1960). However Green, Oldewurtel, O'Doherty, and Forster (1958) observed significantly raised transaminase levels in the CSF of some of their patients with primary tumours of the CNS, and Mellick and Bassett (1964) found similar changes in seven of 11 patients with glioblastomas.

Fleisher et al. (1957) found normal CSF LD and GOT activities in four patients with metastatic carcinoma of the CNS, and Myerson, Hurwitz, and Sall (1957) obtained elevated transaminase activity in two of six such patients. In each patient with metastatic malignancy of the brain studied by Wróblewski et al. (1957), and by Wróblewski, Decker, and Wróblewski (1958), raised CSF LD activity was found. Jakoby and Jakoby (1958) detected a significantly elevated mean CSF LD activity in four patients with cerebral metastases and Green et al. (1958) found raised CSF LD and GOT in three of four similar patients. Mann et al. (1960) and Mellick and Bassett (1964) in three patients with cerebral metastases obtained normal transaminase levels. In the present group of 18 patients with metastatic carcinoma of the CNS there was a highly significant elevation of both the LD and GOT of the CSF in all but two patients.

In the light of the present results, the finding of raised CSF LD and GOT activities would strongly suggest the presence of metastatic cancer of the CNS as opposed to primary tumours. It would also appear that these enzyme activities are a more sensitive index of such disease than the CSF protein concentration, as in eight patients with elevated activities of both enzymes the protein concentration of the CSF was normal.

Three patients with spinal block from secondary carcinomatous deposits in the spinal canal had raised CSF LD and GOT activities (case nos. 3, 8, 9, Table I). In contrast with this are four patients with spinal block produced by benign tumours (case nos. 4, 5, 6, 18, Table II) who had normal activities of both enzymes. This finding implies that normal enzyme levels in the presence of spinal block indicates a benign pathology, whereas raised enzyme levels associated with spinal block would seem to indicate a malignant pathology.

Although most previous workers have found no correlation between the increased enzyme activity of the CSF and the degree of malignancy of a tumour the results of Mellick and Bassett (1964) do suggest this. Green, Oldewurtel, and Forster (1959) also found that the LD activity of the CSF was greatest in patients with malignant anaplastic tumours. The present findings of normal enzyme activity in association with primary tumours, but raised activity in association with metastatic tumours, would also seem to indicate some correlation between elevated CSF LD and GOT activities and the degree of malignancy, as it is implicit that metastatic tumours are highly malignant. Again in support of this is the fact that the patients presented here with primary tumours mostly had slowly growing welldifferentiated varieties, only two patients having undifferentiated highly malignant growths, one of whom had a marked elevation of the CSF LD activity.

The major source of these enzymes is almost certainly the tumours themselves in contact with circulating CSF. Wróblewksi (1959) has shown that tissue culture medium of malignant cells contains increasingly greater amount of LD with time (GOT was not assayed), whereas tissue culture of benign cells does not produce an increase in the LD content of the medium. The destruction of nervous tissue by the tumour with the release of intracellular enzymes into the CSF is another source. The cerebral oedema associated with very malignant growths results in a variable degree of cerebral hypoxia. This cerebral hypoxia, by producing incompetence of the cell membrane and blood/CSF barrier (Lending, Slobody and Mestern, 1961; Slobody, Yang, Lending, Borrelli, and Tyree, 1957), may also contribute to the increased enzyme levels in the CSF through the 
T A B L E I

METASTATIC CARCINOMA OF THE CENTRAL NERVOUS SYSTEM

\begin{tabular}{|c|c|c|c|c|c|}
\hline \multirow[b]{2}{*}{ Case no. } & \multirow[b]{2}{*}{ Age } & \multirow[b]{2}{*}{$\begin{array}{l}\text { Protein } \\
(m g \%)\end{array}$} & \multicolumn{2}{|c|}{$C S F$} & \multirow[b]{2}{*}{ Essential features } \\
\hline & & & $\underset{(u .)}{L D}$ & $\begin{array}{l}G O T \\
(m l .)\end{array}$ & \\
\hline 1 & 63 & 40 & 60 & 25 & $\begin{array}{l}\text { Squamous carcinoma } \\
\text { right upper lobe bronchus } \\
\text { Brain-stem secondary } \\
\text { deposits }\end{array}$ \\
\hline 2 & 59 & 120 & 45 & 20 & $\begin{array}{l}\text { Adenocarcinoma right } \\
\text { middle lobe bronchus. } \\
\text { B1ain-stem deposits }\end{array}$ \\
\hline 3 & 41 & 220 & 175 & 35 & $\begin{array}{l}\text { Invasive renal cell } \\
\text { carcinoma. Paraplegia. } \\
\text { Spinal secondary deposit } \\
\text { T11. Spinal block }\end{array}$ \\
\hline 4 & 53 & 35 & 115 & $22 \cdot 5$ & $\begin{array}{l}\text { Bronchogenic adeno- } \\
\text { carcinoma. Cerebral } \\
\text { metastases }\end{array}$ \\
\hline 5 & 58 & 80 & 45 & 20 & $\begin{array}{l}\text { Oat cell bronchogenic } \\
\text { carcinoma }\end{array}$ \\
\hline & & 35 & 47 & 27 & Metastases cauda equina \\
\hline 6 & 57 & 50 & $86 \cdot 4$ & $22 \cdot 5$ & $\begin{array}{l}\text { Carcinoma breast, } \\
\text { encephaloid type. } \\
\text { Cerebral metastases }\end{array}$ \\
\hline 7 & 65 & 45 & 45 & 18 & $\begin{array}{l}\text { Bronchogenic carcinoma } \\
\text { Cerebral metastases }\end{array}$ \\
\hline 8 & 58 & 275 & 45 & 20 & $\begin{array}{l}\text { Oat cell bronchogenic } \\
\text { carcinoma. Paraplegia. } \\
\text { Secondary deposit T6. } \\
\text { Spinal block }\end{array}$ \\
\hline 9 & 48 & 300 & 40 & $17 \cdot 5$ & $\begin{array}{l}\text { Myelomatosis. Cervical } \\
\text { and cauda equina } \\
\text { secondary deposits. } \\
\text { Spinal block }\end{array}$ \\
\hline 10 & 59 & 65 & $57 \cdot 5$ & 17 & $\begin{array}{l}\text { Anaplastic bronchogenic } \\
\text { carcinoma. Cerebral } \\
\text { metastases }\end{array}$ \\
\hline 11 & 54 & 20 & 104 & $25 \cdot 8$ & $\begin{array}{l}\text { Squamous bronchogenic } \\
\text { carcinoma. Cerebellar } \\
\text { metastasis }\end{array}$ \\
\hline 12 & 57 & 25 & 51 & $22 \cdot 3$ & $\begin{array}{l}\text { Carcinoma breast. } \\
\text { Brain-stem metastases }\end{array}$ \\
\hline 13 & 64 & 110 & 50 & 19 & $\begin{array}{l}\text { Carcinoma rectum. } \\
\text { Metastases to cauda } \\
\text { equina }\end{array}$ \\
\hline 14 & 67 & 160 & 177 & 30 & $\begin{array}{l}\text { No primary tumour } \\
\text { found at necropsy. } \\
\text { Metastatic carcinoma } \\
\text { meninges. Cerebellar } \\
\text { metastases }\end{array}$ \\
\hline 15 & 54 & 110 & 20 & $7 \cdot 5$ & $\begin{array}{l}\text { Bronchogenic carcinoma } \\
\text { Cerebral and spinal } \\
\text { secondaries }\end{array}$ \\
\hline 16 & 73 & 35 & 15 & $12 \cdot 5$ & $\begin{array}{l}\text { Bronchogenic papillary } \\
\text { adenocarcinoma. } \\
\text { Cerebral metastases }\end{array}$ \\
\hline 17 & 67 & 40 & 37 & $15 \cdot 5$ & $\begin{array}{l}\text { Ar.aplastic bronchogenic } \\
\text { carcinoma. Secondary } \\
\text { deposit right cerebral } \\
\text { hemisphere, focal } \\
\text { seizures, and left } \\
\text { hemiparesis }\end{array}$ \\
\hline 18 & 71 & 160 & 39 & $16 \cdot 6$ & $\begin{array}{l}\text { Peripheral neuropathy. } \\
\text { Cerebellar degeneration. } \\
\text { Upper dorsal pain. } \\
\text { Lumbar pain with } \\
\text { sciatica. Lymphatic } \\
\text { leukaemia }\end{array}$ \\
\hline
\end{tabular}

passage into it of intracellular and serum enzymes. Relevant to these points was the finding of large metastatic deposits in contact with the CSF and
T A B L E II

PRIMARY TUMOURS CENTRAL NERVOUS SYSTEM

\begin{tabular}{|c|c|c|c|c|c|}
\hline \multirow[b]{2}{*}{ Case no. } & \multirow[b]{2}{*}{ Age } & \multirow[b]{2}{*}{$\begin{array}{l}\text { Protein } \\
(m g \%)\end{array}$} & \multicolumn{2}{|r|}{$C S F$} & \multirow[b]{2}{*}{ Site and type of neoplasm } \\
\hline & & & $\begin{array}{r}L D \\
(u .\end{array}$ & $\begin{array}{l}\text { GOT } \\
m l .)\end{array}$ & \\
\hline 1 & 54 & 20 & 24 & 10 & $\begin{array}{l}\text { Intrinsic brain-stem } \\
\text { glioma }\end{array}$ \\
\hline 2 & 25 & 55 & 10 & 5 & Cervical ependymoma \\
\hline 3 & 24 & 30 & 15 & 15 & Glioma optic chiasma \\
\hline 4 & 67 & 150 & 20 & $7 \cdot 5$ & $\begin{array}{l}\text { Dorsal meningioma and } \\
\text { spinal block }\end{array}$ \\
\hline 5 & 50 & 700 & 30 & $7 \cdot 5$ & $\begin{array}{l}\text { Neurofibroma C5, } 6 \text { and } \\
\text { spinal block }\end{array}$ \\
\hline 6 & 43 & 110 & 10 & $7 \cdot 5$ & $\begin{array}{l}\text { Dorsal meningioma and } \\
\text { spinal block }\end{array}$ \\
\hline 7 & 57 & 25 & 25 & 15 & Temporal glioma \\
\hline 8 & 31 & 35 & 15 & 10 & Subfrontal meningioma \\
\hline 9 & 63 & 55 & 30 & $12 \cdot 5$ & $\begin{array}{l}\text { L. posterior parietal } \\
\text { grade IV astrocytoma }\end{array}$ \\
\hline 10 & 51 & 35 & 15 & $7 \cdot 5$ & Craniopharyngioma \\
\hline 11 & 7 & 160 & 25 & $12 \cdot 5$ & $\begin{array}{l}\text { Grade I ependymoma } \\
\text { with areas of oligoden- } \\
\text { droglial proliferation }\end{array}$ \\
\hline 12 & 47 & 170 & 20 & 10 & Acoustic neurofibroma \\
\hline 13 & 70 & 120 & 15 & $7 \cdot 5$ & Acoustic neurofibroma \\
\hline 14 & 8 & 40 & 10 & 10 & $\begin{array}{l}\text { Grade I fibrillary } \\
\text { astrocytoma invading } \\
\text { ventricle }\end{array}$ \\
\hline 15 & 57 & 130 & 150 & $12 \cdot 5$ & Astrocytoma, grade IV \\
\hline 16 & 22 & 45 & 10 & 5 & $\begin{array}{l}\text { Dorsal haemangioendo- } \\
\text { thelioma }\end{array}$ \\
\hline 17 & 26 & 120 & 35 & $12 \cdot 3$ & Glioma opt ic nerve \\
\hline 18 & 61 & 140 & 25 & $7 \cdot 5$ & $\begin{array}{l}\text { Dorsal meningioma and } \\
\text { spinal block }\end{array}$ \\
\hline
\end{tabular}

accompanied by extensive cerebral oedema in eight of the nine patients who came to necropsy.

From the clinical point of view, the finding of raised CSF LD and GOT activities would strongly favour the presence of metastatic carcinoma of the central nervous system, or possibly a highly malignant primary tumour. This suggestion is further emphasized by the fact that, of 500 patients studied, this pattern of enzyme change was found only in such patients. It also suggests that with these enzyme changes conservative management would seem indicated.

\section{SUMMARY}

The cerebrospinal fluid lactate dehydrogenase and glutamic oxalacetic transaminase activities were measured in 36 patients with neoplastic disease of the central nervous system. Elevated activities of both enzymes were associated with metastatic carcinoma of the CNS. Patients with primary tumours on the whole had normal levels, but most of these had benign tumours. These findings may be of value in distinguishing between metastatic and primary, especially benign primary, tumours of the central nervous system.

I am indebted to Dr. James Carson for his support and encouragement throughout this study, and am most 
grateful to him and to Dr. J. P. P. Bradshaw for their advice and for allowing me to study their patients. 1 wish to thank Professor C. H. Stuart-Harris for providing the laboratory space and facilities of the University Department of Medicine, and all the physicians of the United Sheffield Hospitals for allowing me to see their patients.

\section{REFERENCES}

Fawcett, C. P., Ciotti, M. M., and Kaplan, N. O (1961). Inhibition of dehydrogenase reactions by a substance formed from reduced diphosphopyridine nucleotide. Biochim. biophys. Acta (Aust.), $54,210-212$.

Fleisher, G. A., Wakim, K. G., and Goldstein, N. P. (1957). Glutamicoxalacetic transaminase and lactic dehydrogenase in serum and cerebrospinal fluid of patients with neurologic disorders. Mayo Clin. Proc., 32, 188-197.

Green, J. B., Oldewurtel, H. A., and Forster, F. M. (1959). Glutamic oxalacet ic transaminase (GOT) and lact ic dehydrogenase (LDH) activities. Study in the cerebrospinal fluid of brain tumor patients, in normal human brain and in brain tumor homogenates. Neurology (Minneap.), 9, 540-544.

, O'Doherty, D. S., and Forster, F. M. (1958). Cerebrospinal fluid transaminase and lactic dehydrogenase activities in neurologic disease. Arch. Neurol. Psychiat. (Chic.), 80, 148-156. _ _ _ - and Sanchez-Longo, L. P. (1957). Cerebrospinal fluid glutamic oxalacetic transaminase activity in neurologic disease. Neurology (Minneap.), 7, 313-322.

Jakoby, R. K., and Jakoby, W. B. (1958). Lactic dehydrogenase of cerebrospinal fluid in the differential diagnosis of cerebrovascular disease and brain tumor. J. Neurosurg., 15, 45-51.

Karmen, A. (1955). A note on the spectrophotometric assay of glutamic-oxalacetic transaminase in human blood serum. $J$. clin. Invest., 34, 131-133.

Katzman, R., Fishman, R. A., and Goldensohn, E.S. (1957). Glutamicoxalacetic transaminase activity in spinal fluid. Neurology (Minneap.), 7, 853-855.

Lending, M.. Slobody, L. B., and Mestern, J. (1961). Effect of prolonged hypoxia on cerebrospinal fluid and plasma activity of GOT and LDH. Ibid., 11, 520-523.

Mann, S. H., DePasquale, N., and Paterson, R. (1960). Cerebrospinal fluid glutamic oxalacetic acid transaminase in patients receiving electroconvulsive therapy and in neurologic diseases. Ibid., 10, 381-390.

Mellick, R. S., and Bassett, R. L. (1964). The cerebrospinal-fluid glutamic oxalacetic transaminase activity in neurological diseases. Lancet, 1, 904-906.

Myerson, R. M., Hurwitz, J. K., and Sall, T. (1957) Serum and cerebrospinal-fluid transaminase concentrations in various neurologic disorders. New. Engl. J. Med., 257, 273-276.

Slobody, L. B., Yang, D. C., Lending, M., Borrelli, F. J., and Tyree, M. (1957). Effect of severe hypoxia on blood-cerebrospinal fluid barrier. Amer. J. Physiol., 190, 365-370.

Wróblewski, F. (1959). Increasing clinical significance of alterations in enzymes of body fluids. Ann. Int. Med., 50, pt. 1, 62-93.

- Decker, B., and Wróblewski, R. (1957). Activity of lactic dehydrogenase in spinal fluid. Amer. J. clin. Path., 28, 269-271.

- , and - (1958). The clinical implications of spinal-fluid lactic dehydrogenase activity. New Engl.J. Med., 258, 635-639.

- , and LaDue, J. S. (1955). Lactic dehydrogenase activity in blood. Proc. Soc exp. Biol. (N.Y.), 90, 210-213. 